\title{
A FRAMEWORK FOR APPLYING INTEGRATED VEGETATION MANAGEMENT ON RIGHTS-OF-WAY
}

\author{
By Christopher A. Nowak ${ }^{1}$ and Benjamin D. Ballard ${ }^{2}$
}

\begin{abstract}
Integrated Vegetation Management, or IVM, is purportedly being used by many right-of-way management organizations across the United States. In many cases, IVM is just a name applied to old management approaches. Yet IVM is more than just a name. It is an in-depth and sophisticated system of information gathering, planning, implementing, reviewing, and improving vegetation management treatments. IVM is used to understand, justify, choose among, selectively apply, and monitor different types of treatments, with an overall goal of eliciting sitespecific, ecosystem-sensitive, economically sensible, and socially responsible treatment effects that lead to refined achievement of management objectives. We propose a six-step system to IVM that can act as a framework of activities to aid managers and other related stakeholders in communicating, organizing, and conducting IVM business. Each step produces information that must be integrated into the management system. Our six-step system is consistent with Integrated Pest Management and other IVM-like systems developed in forestry and agriculture. We present an IVM system with some unique perspectives and ideas from the literature, and incorporate information from and experience with the electric utility industry.
\end{abstract}

Key Words. Right-of-way; vegetation management; management systems; powerline corridors; electric transmission lines; pipelines; highway; railroad.

Rights-of-way (ROWs) can be generally defined as units of land used for transportation. As such, ROWs provide many goods, values, and services important to society. Production of values and services can occur from the ROW itself via the act of transport, such as with the movement of people in cars, trucks, and trains. Benefits of ROWs can accrue from the movement of goods, such as gas, oil, and electricitythese goods hold the benefit, and ROWs are a means of transmitting or distributing them to a place where the direct benefit is secured.

All ROWs are managed with a general goal of providing safe and reliable transport. Managers endeavor to meet this goal by creating corridors that exist in narrowly defined technical and environmental states. In almost all ROW scenarios, active management is needed to create specific vegetation and related environmental conditions. On electric transmission line ROWs, the selective removal of tall-growing trees and promotion of low-growing, relatively stable plant communities composed of grasses, forbs, and shrubs is the common approach to vegetation management. Tall-growing trees can cause unsafe conditions and shortfalls in reliability by growing into or near the wire conductors. These trees act as conduits for electricity, causing ground-fault disruptions in transmission. ROWs fully occupied by low-growing plants have been shown to produce safe, reliable, cost-effective transmission of electricity, primarily because, over the long-term, they result in a minimal amount of undesirable trees (Egler 1953; Niering 1958; Nowak and Abrahamson 1993; Finch and Shupe 1997; Jackson 1997).

Tree seeds and seedlings are consumed by small mammals that find suitable cover in the low-growing plants. When trees do become established, their growth and development are minimized by interference from the lowgrowing plant community (Bramble and Byrnes 1983; Hill et al. 1995; Bramble et al. 1996). Reduced and minimized tree populations lead to a reduction in management inputs. Herbicide use can be halved when this selective vegetation management approach is used, compared to other lessdiscriminate approaches such as broadcast spraying (Nowak and Abrahamson 1993; Finch and Shupe 1997). In addition to providing desirable corridor conditions for the transport of electricity and minimization of management costs, ROWs managed for complex, low-growing plant communities provide a wide variety of environmental values, benefits, and services, particularly associated with wildlife (Nowak 2002; Yahner 2004).

The idea of selective tree removal to manage powerline ROWs was first proposed 50 years ago (Egler 1953; Niering and Egler 1955; Niering 1958), with numerous, subsequent re-propositions (Niering and Goodwin 1974; Dreyer and Niering 1986; Niering et al. 1986; Bramble et al. 1990; Nowak and Abrahamson 1993). Over the past five decades, herbicides have been presented as both the optimum way of controlling the pest (the tall-growing trees) and a treatment that minimizes its own use in the long run, as explained above.

The selective vegetation management approach has been a part of New York State regulations since 1980 (Nowak and Abrahamson 1993; Jackson 1997; McLoughlin 2002). Other states and regions have also adopted this approach to vegetation management (Van Bossuyt 1987; Daar 1991; Bramble and Byrnes 1996; Wells et al. 2002). 
In the 1980s, the selective vegetation management approach was first compared to Integrated Pest Management (IPM), as it was clear that the selective control of tree pests followed the core precepts of IPM- "prevention" and "integrated control" (sensu Stern et al. 1959). Because it was not clear that all of the precepts and principles of IPM applied to vegetation management on powerline corridors, and, given that for many people it is difficult to view trees as "pests," the phrase "Integrated Vegetation Management" was coined (Jackson 1997; McLoughlin 2002). Efforts to apply IPM in other plant systems have resulted in similar phrases to describe vegetation management systems, such as "Integrated Weed Management" in agriculture (Swanton and Weise 1991) and "Integrated Forest Vegetation Management" in forestry (Wagner 1994).

Within IVM, various key elements of IPM systems have only recently been developed or recognized. Some examples include (after McLoughlin 1997, 2002) the following:

- managing a pest with integrated control measures, including prevention and an emphasis on biological control (liken to the use of low-growing plant communities to naturally control pest tree populations);

- a growing emphasis on monitoring and assessment (including refined efforts to document a pest problem);

- decisions based on tolerance levels;

- professional-grade prescriptions of treatments; and

- formalized efforts to determine long-term efficacy and effectiveness of treatments.

Our paper presents the next evolution in IVM along an IPM path: development of a full systems approach. We present a refined system for guiding the assessment and application of IVM on ROWs as an adaptation of an Integrated Pest Management model developed by Witter and Stoyenoff (1996) for insects in urban systems. In our system, IVM is viewed as a series of six steps that formalize the relationships among critical phases of vegetation management (Figure 1):

1. understanding pest and ecosystem dynamics;

2. setting management objectives and tolerance levels;

3. compiling treatment options;

4. accounting for economic and environmental effects of treatments;

5. site-specific implementation of treatments; and

6. adaptive management and monitoring

These steps are not the same as those in Witter and Stoyenoff (1996); we have tailored them to better match application of IVM on ROWs.

We have found our IVM system to be useful in organizing research programs on pipeline, roadside, and electric transmission ROWs. Through interacting with various ROW vegetation managers over the past few years, we have

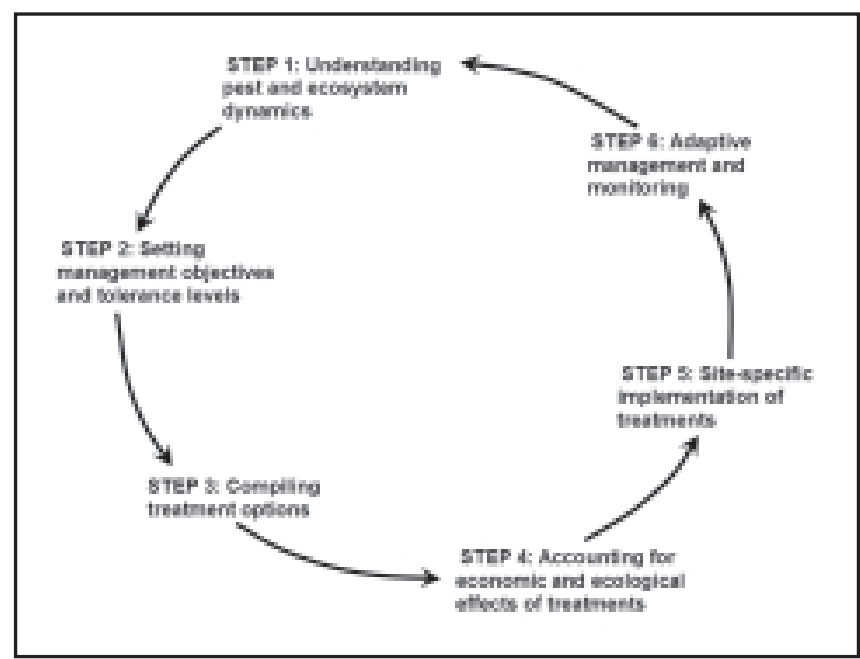

Figure 1. Component steps of Integrated Vegetation Management, a system for managing rights-of-way vegetation (adapted from Nowak and Ballard 2001, and Nowak 2002, from Witter and Stoyenoff 1996).

received favorable comments on the "utility" (no pun intended) of our IVM system framework for vegetation management operations. Recently, a variation of our system was used to describe wildlife considerations on ROWs (Nowak 2002).

Examples of system-level frameworks for vegetation management do exist. A stepwise framework similar to ours was described by IPM Associates (1996) as a model for vegetation management, as follows:

1. Gather background information and conduct weed inventories.

2. Set management objectives.

3. Establish monitoring programs to inventory weed growth stages, locations, and acreage infested.

4. Set treatment action levels and thresholds to determine whether treatment is necessary.

5. Use weed prevention measures and revegetation in management plans.

6. Apply effective, least-toxic management methods.

7. Educate the public.

8. Evaluate the program.

There is some similarity between our steps and those developed by IPM Associates (1996), but, given that most management systems involve patterns of information gathering, planning, implementing, reviewing, and improving vegetation management treatments, the similarity is not surprising

Our system-level framework differs from other frameworks of IPM/IVM in two main ways:

- We present the system as a series of cyclical steps rather than a linear progression. A cyclic portrayal 
underscores integration of steps and emphasizes continual self-improvement.

- We focus on the elements and information that are to be integrated into the system with each step. This idea of "integration" is critical, yet it seems to be overlooked in most portrayals of IPM and IVM. Each of our steps provides information that needs to be integrated into the system. Failure to integrate any one element in a step could prevent the development of a fully functioning management system.

In this paper, we present a working framework for an IVM system using a cyclical series of six steps. Each step and its accompanying description are meant to promote broad considerations for ecological, environmental, economic, and social opportunities and constraints for vegetation management.

We outline general concepts and cite key references for each step. Specific methods for each step should be developed by the reader through further study and practice. Also, the reader should recognize that the steps are a simplification of what is an extremely complex system. It is, after all, this complexity that requires professionals to conduct IVM.

Because the electric utility industry has led the development of IVM and is rich with documented effort in all steps, we provide references that are mostly related to vegetation management on electric transmission line ROWs. More general references are provided when ROW experience is lacking. While we focus the paper on the electric utility industry, it must be recognized that this systematic approach of IVM is applicable to all systems, including ROWs, where plants are pests.

Our goal with this paper is to provide a useful framework to foster assessment and application of IVM. Organizations and people may then better assess their actions and understand how to more fully apply and communicate about IVM.

\section{A STEPWISE SYSTEM TO INTEGRATED VEGETATION MANAGEMENT ON ELECTRIC TRANSMISSION LINE RIGHTS-OF-WAY Step 1: Understanding Pest and Ecosystem Dynamics}

A first step to conducting IVM is to develop a working knowledge of the organisms in the managed system and how they interact with each other and the environment, with or without vegetation management, to produce ecosystem conditions. ROW vegetation management necessarily puts a focus on controlling vegetation conditions, but all organisms affected by management should be considered. Basic knowledge of plants and animals is critical, starting with species identification through to understanding life histories (reproduction, growth, and longevity), plant strategies, and responses to disturbance (Wagner and Zasada 1991).

In plant-dominated systems, changes in distribution and abundance of plants through time and space (referred to as plant succession for communities) must be understood (Niering 1958; Bramble 1980; Niering 1987; Luken 1990). Plants and plant communities are manipulated to control the rate and direction of plant succession via control of various mechanisms, such as interference and herbivory. Vegetation management affects these and other mechanisms by changing plant community composition and structure through type, timing, intensity, and scale of disturbance, which affect interference patterns and wildlife habitat. Models that describe these interactions and outcomes (e.g., see Bramble et al. 1991) are useful in portraying vegetation dynamics with different types of management, and in planning and communicating with stakeholders.

\section{Step 2: Setting Management Objectives and Tolerance Levels}

Step 2 is where people first fully enter the cycle of IVM. Although IVM is challenging and potentially complex, managers must articulate objectives and tolerance levels of a multitude of stakeholders, as well as ecological and engineering constraints. Transmission of electricity exacts very specific requirements so that safety and reliability of service is maintained-no tall-growing trees under or near the conductors. The type of vegetation or other land uses that can occur may vary considerably from one location to the next. People, or, more specifically, stakeholders, can participate in deciding what type of ROW condition is satisfactory to them.

Stakeholders include vegetation management professionals responsible for management decisions on a particular ROW, landowners of the ROW or adjacent properties, governmental regulators responsible for administering state and federal policies and laws, and nongovernmental organizations with a general concern for the environment. In addition to viewing powerline corridors for the transport of electricity, stakeholders value these types of ROWs for wildlife habitat, recreation opportunities, and conservation (Niering 1958; Glaholt et al. 1995; Hay and Mohrman 1995). All stakeholders need to be engaged in the process of developing management objectives, framing the issues, and providing perspectives and opinions (Buchanan 1995; Clark et al. 1995; Johnstone 1995; Shupe et al. 1997).

Stakeholders are often concerned with risks to human health and well-being associated with treatment of ROW vegetation, particularly with herbicides (Wagner 1994; Norris et al. 2002). ROW vegetation managers must learn to recognize and acknowledge needs of other interested parties and adjust management to accommodate where possible. However, it is rare that all parties can be satisfied in 
a specific situation. Ultimately, the decision on how to compromise, or not, and best manage any one section of a ROW lies in the hands of the professional vegetation manager.

An important aspect of communication with stakeholders revolves around the concept of "tolerance levels" (see Stern et al. 1959). Tolerance levels are specific descriptions of vegetation condition-individual plant and plant community size, abundance, and composition-that, if exceeded, trigger a need to intervene. Inventory and monitoring are a part of IVM (see Steps 5 and 6). Pests are not treated unless they exceed the critical threshold. Well-defined thresholds are an important element of IVM (McLoughlin 1997, 2002) that can be useful in communicating management needs to various stakeholders; for example, thresholds and tolerance levels can be used to demonstrate the cyclic nature of vegetation dynamics, which supports a need to control vegetation on a regular basis.

\section{Step 3: Compiling Treatment Options}

Singular use of any one treatment method across all sites and conditions is not an IVM approach. ROW vegetation managers can conduct IVM only if multiple treatment options are available for application to any one site and in any one setting. Different treatment options may be needed to match variable environmental and site conditions on a ROW (see Step 5) or to address other stakeholder concerns and interests (see Step 2).

Vegetation treatments can be grouped into categories, such as mechanical, chemical, cultural, physical, biological, and ecological (McLoughlin 1997, 2002). It is most common to use two or more of these categories of treatment on any one site at any one time (e.g., the cut-stump method of killing trees combines mechanical and chemical treatments and leads to the biological/ecological control associated with removing individual trees on ROWs, as explained at the beginning of this paper). IVM does focus on integrating biological/ecological control into all treatment schemes. Such control prevents the buildup of pest populations, which is a critical element of the integrated control concept (Stern et al. 1959) and IPM (McLoughlin 1997, 2002). A primary objective of vegetation management in an IVM system on powerline corridors should be to create stable, low-growing plant communities, which leads to a reduction in pest (tree) populations (Niering and Goodwin 1974). This biological/ecological control produces a long-term reduction in treatment efforts and a reduction in herbicide use (Nowak and Abrahamson 1993; Finch and Shupe 1997).

\section{Step 4: Accounting for Economic and Environmental Effects of Treatments}

Choice of treatment must be made with an understanding of potential socioeconomic and environmental impacts.
Approaches to this can be unique to each person and company. A useful metric is cost effectiveness (see Nowak et al. [1992] and Abrahamson et al. [1995] for details on use and application, based on research and development studies). Cost effectiveness is a measure of the success of a treatment in terms of economics, plant community dynamics, and related environmental considerations. It can be defined by its two component parts: cost and effectiveness. Cost for ROW vegetation management can be viewed as including direct costs and indirect costs. Direct costs pertain to the actual outlay of money made to treat ROW vegetation. Labor, equipment, and materials are commonly reported as direct costs. Indirect costs are the loss or nonproduction of values or service that can result from a treatment. These are often associated with water quality, wildlife habitat, and aesthetics, or other ways that the environment can be degraded. They are sometimes referred to as "environmental externalities," though environmental externalities can be either positive or negative, depending on whether they are a benefit or a cost. Other indirect costs are associated with risk of treatment to human health, and related pollution of soil, air, and sound (noise). Actual dollar amounts are difficult to ascribe to indirect costs.

Effectiveness pertains to production of desired vegetation conditions and associated benefits and values, including safe and reliable transmission of electricity, promotion of diverse plant and animal communities, protection of riparian areas and water quality, creation of visual attributes fashioned to minimize negative impacts to aesthetic appeal or quality, and enhancement of opportunities for recreational endeavors.

Time frames for consideration of cost effectiveness can be short- or long-term. Because vegetation management and the IVM process is a long-term affair, efforts must be made to balance short-term savings with long-term costs. For example, it may be less costly, monetarily, to mow a ROW today than use herbicides. Mowing may produce higher costs over the long-term because of short-term control of vegetation conditions and shorter treatment cycles than can be achieved with other treatments (e.g., see Johnstone 1990; Nowak et al. 1995).

Vegetation managers need to select the most costeffective treatment for each ROW management scenario. Because no two situations are alike, different treatments are often needed to maximize cost effectiveness (see Step 5). In general, we expect that treatments will lead to a reduction in the pest organism (trees) and will minimize (prevent) further development of a problem, which will lead to a reduction in management inputs and a reduction in both direct and indirect costs. IVM equates to using treatments that are least costly in terms of dollars, produce minimal risks for human health and the environment, and create the desired vegetation conditions and associated positive values or externalities associated with these conditions over the long-term. 
Said differently, IVM is used to maximize cost effectiveness of management efforts.

\section{Step 5: Site-Specific Implementation of Treatments}

A key element of IVM is the use of prescriptions to describe and document decisions on treatment methods for different circumstances of vegetation management. Prescriptions include a presentation of desired future conditions of the ROW area to be treated, description of the treatment as a function of current vegetation conditions, and justification of treatments as a function of ecological, socioeconomic, and administrative considerations (Florence 1977; Beaufait et al. 1984; Province of British Columbia 2000). Treatment recommendations are the crucial part of the prescription. After developing a suite of treatment options (Steps 2, 3, and 4) and weighing the effects of those treatments on longterm production of vegetation conditions and associated benefits and values, a treatment is chosen by the professional vegetation manager.

Blanket prescriptions should not be written for whole ROWs but instead developed for specific sections of any one ROW. There are many examples of site-specific treatment needs in ROW vegetation management. Water resources (e.g., streams and wetlands) are protected by the use of edge buffers where specific treatments may be applicable. Buffer widths may vary as a function of the type of treatment (Environmental Consultants 1991). Site-specific management may also occur across and along ROWs via a two-zone concept. In the "wire zone/border zone" two-zone approach, the edges or border zone of the ROW are treated differently than the center or wire zone of the ROW (Niering 1958; Bramble et al. 1985; Ballard et al. 2004). Vegetation along the centerline can be kept in herbaceous plant and short shrub communities to allow ready access to transmission facilities, whereas the edges of the ROWs are kept in taller shrubs and short trees. Both conditions are produced using different vegetation management treatments and have been shown to produce diverse elements of wildlife habitat (Bramble et al. 1985, 1992, 1997; Yahner et al. 2001).

It is critical to have well-educated and trained professionals making these decisions, because of the complexity in doing so in the context of IVM (Abrahamson et al. 1995). It is important to base treatment choices on inventory and analysis of existing site and vegetation conditions (Dykes 1980; Alkiewicz et al. 2002), particularly because these data will be critical in monitoring outcomes of treatments (see Step 6).

\section{Step 6: Adaptive Management and Monitoring}

Adaptive management is formalization of the process of learning from experience (Baskerville 1985). Effects of treatments are monitored over successive cycles. Amount of materials used in treatment, treatment costs, and vegetation conditions before and after treatment are quantified. System performance (reliability) is documented. A wide variety of system elements can be monitored, such as tree populations (Johnstone 1990; Nowak et al. 1995; Finch and Shupe 1997), herbicide use in conjunction with plant community changes with management over time (Finch and Shupe 1997), herbicide residuals with chemical treatments (Norris 1997), water quality (Peterson 1993; Garant et al. 1997), and wildlife populations (Doucet and Brown 1997; Doucet and Garant 1997; Ricard and Doucet 1999). Data collection and record keeping that produce credible, factual information is a requirement of effective monitoring, as is skilled analysis of the data (Norris 1997). Vegetation conditions are compared to the desired condition set during the "management objectives and tolerance levels" step (Step 2) and described in prescriptions during the "site-specific implementation of treatments" step (Step 5). Any disparities between "desired" and "achieved" results are investigated, and future treatment options are adjusted accordingly. Monitoring in an IVM program assures stakeholders that treatment effects are gauged and shortfalls are corrected by improving management schemes to better accomplish management objectives.

\section{SUMMARY AND CONCLUDING REMARKS}

IVM is a complex of basic and applied knowledge, coupled with high-intensity management effort. It is used to understand, justify, choose among, selectively apply, and monitor different types of treatments, with an overall goal of eliciting site-specific, ecosystem-sensitive, economically sensible, and socially responsible treatment effects that lead to refined achievement of management objectives.

IVM is described in this paper as a system based on a continuous cycle of information gathering, planning, implementing, reviewing, and improving vegetation management treatments and the related actions that a utility or other management organization could undertake to meet its business and environmental needs. Systematic steps of IVM can be used to frame efforts by utilities to manage vegetation based on science but also with artistry that comes from experience and a sense of the management situation from site-specific inventories and awareness of socioeconomic constraints and opportunities.

IVM differs from past management approaches to managing vegetation on ROWs in its greater breadth and complexity of management considerations and in its higher level of sophistication and effort in evaluating management choices. In this paper, we portray how the basic steps of IVM relate to each other. Applying all IVM steps is the only way to derive full system benefits. Critical information (categorized below in italics) is being produced at each step:

Step 1: Basic knowledge—rudimentary ecological understanding of the biotic (plants and animals) and abiotic components of the managed system, with an aim to under- 
standing why and how individuals and ecosystems function certain ways and variably respond to disturbance (e.g., management);

Step 2: Stakeholder perspectives-input from affected people with regard to objectives for, and objections to, management;

Step 3: A "toolbox" full of treatments—development of a cadre of methods to produce desired plant or plant system effects;

Step 4: Applied knowledge — an accounting of all direct and indirect costs and benefits, usually via measures of cost effectiveness and applied research that serves to address how treatments affect ROW ecosystems and socioeconomics;

Step 5: Prescriptions-expectations of treatment needs and responses on a site- and pest-specific basis; and

Step 6: Experience-monitoring treatment effects as a basis for adaptation and improvement.

Elements of information acquired from each step can be used to support subsequent steps (see Figure 1), or information from any one step can be integrated into other steps (Figure 2). The steps are not necessarily used in sequence. Many steps can occur simultaneously.

IVM focuses on continual improvement. It is the sense of improvement that draws the circle of steps to close in the form of a self-improving cycle (Figures 1 and 2). With new

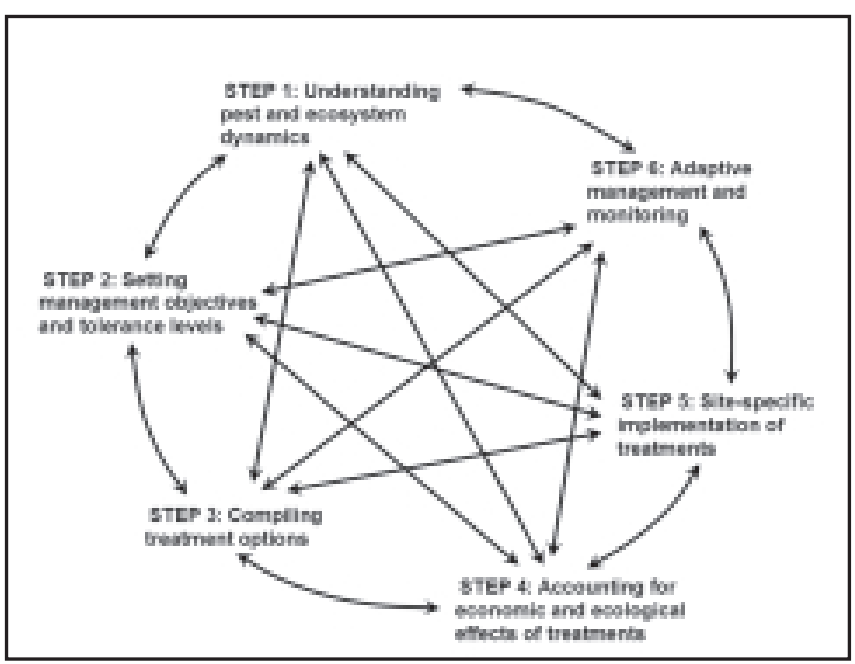

Figure 2. Component steps of Integrated Vegetation Management showing the cross-linkages among steps.

knowledge gained from completing an IVM cycle, the process is begun anew with heightened understanding of the ROW system and awareness of the opportunities and potential shortfalls of management. Each cycle of management builds on the previous cycle to build a rising, expanding spiral of accomplishment and professional development (Figure 3).

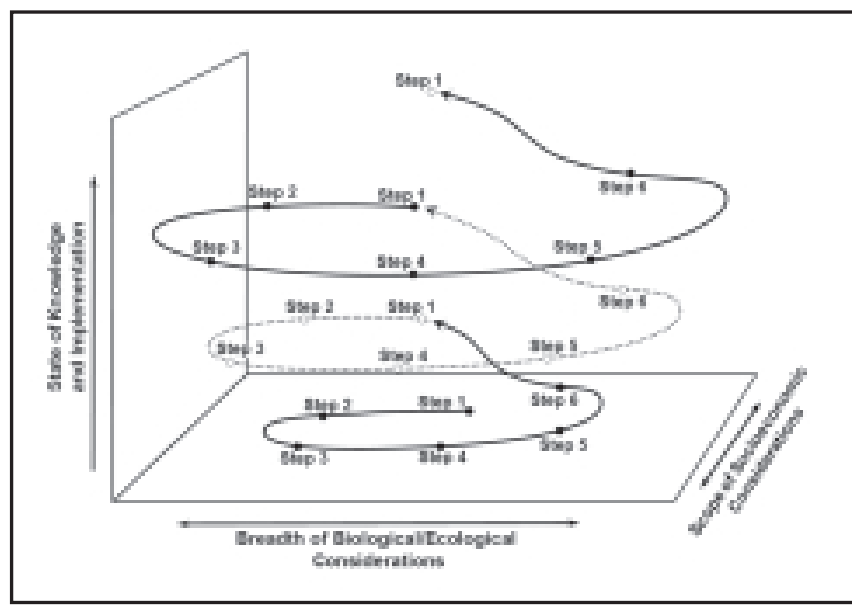

Figure 3. Three complete iterations of the six-step Integrated Vegetation Management system demonstrating the self-improving nature of IVM. Each complete iteration expands the scope of the management considerations, elevates the level of knowledge, and increases success of implementation.

To conduct IVM according to our six step system, managers must fully consider the following questions (these numbers correspond to the step numbers associated with our IVM system):

1. Do you have a detailed, basic knowledge of the managed ecosystem?

2a. Do you actively and broadly involve stakeholders in vegetation management decisions?

2b. Do you consider tolerance levels when determining the need to treat vegetation (positive approach), or do you take a rote approach and treat vegetation only routinely (negative approach)?

2c. Are you proactive in vegetation management (e.g., treat vegetation in concert with tolerance levels, with decisions based on inventory and planning) or reactive (e.g., "hot spotting," where vegetation is treated after thresholds are soon to be, or already, exceeded)?

3a. Do you maintain a broad range of vegetation treatments-mechanical, chemical, cultural, and biological —in your "toolbox" and apply a variety of treatments depending on the site and vegetation conditions?

3b. Do you foster the use of biological/ecological controls to prevent pest populations from building beyond economic thresholds?

4. Do you use broad considerations of cost effectiveness in selecting a treatment for a specific site?

5. Do you prescribe treatments in a site-specific manner, based on a contemporary inventory of ROW resources?

6. Do you monitor the results of treatments to compare actual conditions to desired future conditions, and look to improve the system based on that comparison? 
Answers to these questions are the crux to a systems approach to IVM and to the application of IVM itself. However, it is important to recognize that these steps do not represent the only way of going about the ROW management business. There may be other steps appropriate for any one organization, and how the steps are woven together in the larger ROW management plan may differ among organizations. We do feel that all IVM programs should include our steps, and we challenge practitioners to recognize that it is only with the integration of information from all steps that IVM can be claimed as a management approach.

\section{LITERATURE CITED}

Abrahamson, L.P., C.A. Nowak, P.M. Charlton, and P.G. Snyder. 1995. Cost effectiveness of herbicide and nonherbicide vegetation management methods for electric utility rights-of-way in the Northeast: State-of-the art review, pp 27-43. In Doucet, G.J., C. Séguin, and M. Giguère (Eds.). Proceedings of the 5th International Symposium on Environmental Concerns in Rights-of-Way Management, September 19-22, 1993, Montréal, QC.

Alkiewicz, E., J. Wingfield, D. Frazier, and L. Khitrik. 2002. Using GIS tools to conduct environmental and asset analyses along rights-of-way, pp. 29-45. In GoodrichMahoney, J.W., D.F. Mutrie, and A. Guild (Eds.). Proceedings of the 7th International Symposium on Environmental Concerns in Rights-of-Way Management, September 9-13, 2000, Calgary, AB. Elsevier Science, New York, NY.

Ballard, B.D., H.L. Whittier, and C.A. Nowak. 2004. Northeastern Shrub and Short Tree Identification: A Guide for Right-Of-Way Vegetation Management. Eastwood Litho, Syracuse, NY.

Baskerville, G. 1985. Adaptive management: Wood availability and habitat availability. For. Chron. 61:171-175.

Beaufait, W., P.P. Laird, M. Newton, D.M. Smith, C.H. Tubbs, C.A. Wellner, and H.L. Williston. 1984. Silviculture, pp 413-488. In K. Wenger (Ed.). Forestry Handbook, 2nd edition. Society of American Foresters, John Wiley \& Sons, New York, NY.

Bramble, W.C. 1980. Sound right-of-way program must include plant ecology. Weeds, Trees and Turf, p. 16-18.

Bramble, W.C., and W.R. Byrnes. 1983. Thirty years of research on development of plant cover on an electric transmission right-of-way. J. Arboric. 9(3):67-74.

_ 1996. Integrated vegetation management on an electric utility right-of-way ecosystem. Down to Earth 51(2).

Bramble, W.C., W.R. Byrnes, and R.J. Hutnik. 1985. Effects of a special technique for right-of-way maintenance on deer habitat. J. Arboric. 11(9):278-284.

_-1990. Resistance of plant cover types to tree seedling invasion on an electric transmission right-ofway. J. Arboric. 16(5):130-135.
Bramble, W.C., R.H. Yahner, and W.R. Byrnes. 1997. Effect of herbicides on butterfly populations of an electric transmission right-of-way. J. Arboric. 23(5):196-206.

Bramble, W.C., W.R. Byrnes, R.J. Hutnik, and S.A. Liscinsky. 1991. Prediction of cover type on rights-of-way after maintenance treatments. J. Arboric. 17(2):38-43. . 1996. Interference factors responsible for forbgrass cover types to tree invasions on an electric utility right-of-way. J. Arboric. 22(2):99-105.

Bramble, W.C., R.H. Yahner, W.R. Byrnes, and S.A. Liscinsky. 1992. Small mammals in plant cover types on an electric transmission right-of-way. J. Arboric. 18(6):316-321.

Buchanan, S.A. 1995. Cooperative strategies for rights-ofway management, pp 3-4. In Doucet, G.J., C. Séguin, and M. Giguère (Eds.). Proceedings of the 5th International Symposium on Environmental Concerns in Rights-of-Way Management, September 19-22, 1993, Montréal, QC.

Clark, B.N., J.M. Fly, D.A. Buehler, and R.M. Evans. 1995. Public perception of powerline rights-of-way management, pp 446-449. In Doucet, G.J., C. Séguin, and M. Giguère (Eds.). Proceedings of the 5 th International Symposium on Environmental Concerns in Rights-of-Way Management, September 19-22, 1993, Montréal, QC.

Daar, S. 1991. Vegetation management on rights-of-way: An ecological approach. IPM Practitioner 13(2):1-7.

Doucet, G.J., and D.T. Brown. 1997. Snowshoe hare, red squirrel and gray squirrel winter activity in a $120 \mathrm{kV}$ powerline right-of-way and in adjacent forests, pp 295298. In William, J.R., J.W. Goodrich-Mahoney, J.R. Wisniewski, and J. Wisniewski (Eds.). Proceedings of the 6th International Symposium on Environmental Concerns in Rights-of-Way Management, February 24-26, 1997, New Orleans, LA. Elsevier Science, New York, NY.

Doucet, G.J., and Y. Garant. 1997. White-tailed deer (Odocoileus virginianus) use of forested travel corridors in a twin $735 \mathrm{kV}$ powerline right-of-way-20 years of observations, pp 299-302. In William, J.R., J.W. Goodrich-Mahoney, J.R. Wisniewski, and J. Wisniewski (Eds.). Proceedings of the 6th International Symposium on Environmental Concerns in Rights-of-Way Management, February 24-26, 1997, New Orleans, LA. Elsevier Science, New York, NY.

Dreyer, G.D., and W.A. Niering. 1986. Evaluation of two herbicide techniques on electric transmission rights-ofway: Development of relatively stable shrublands. Environ. Manage.10(1):113-118.

Dykes, A.M. 1980. Right-of-way management program. J. Arboric. 6:74-76.

Egler, F.E. 1953. Vegetation management for roadside and rights-of-way, pp 299-322. In Smithsonian Institution 1953 Annual Report, Smithsonian Institution, Washington, DC. 
Environmental Consultants, Inc. 1991. Determination of the Effectiveness of Herbicide Buffer Zones in Protecting Water Quality on New York State Powerline Rights-ofWay. Report EP 89-44. Empire State Electric Energy Research Corporation, Schenectady, NY.

Finch, K.E., and S.D. Shupe. 1997. Nearly two decades of integrated vegetation management on electric transmission rights-of-way, pp 65-75. In William, J.R., J.W. Goodrich-Mahoney, J.R. Wisniewski, and J. Wisniewski (Eds.). Proceedings of the 6th International Symposium on Environmental Concerns in Rights-of-Way Management, February 24-26, 1997, New Orleans, LA. Elsevier Science, New York, NY.

Florence, R.G. 1977. The silvicultural decision. For. Ecol, Manage. 1:293-306.

Garant, Y., J. Domingue, and F. Gauthier. 1997. Comparative evaluation of erosion and water temperature in small streams located in powerline rights-of-way and in the upstream undisturbed habitat, pp 463-467. In William, J.R., J.W. Goodrich-Mahoney, J.R. Wisniewski, and J. Wisniewski (Eds.). Proceedings of the 6th International Symposium on Environmental Concerns in Rights-of-Way Management, February 24-26, 1997, New Orleans, LA. Elsevier Science, New York, NY.

Glaholt, R.D., G. Fryer, and A. Colette. 1995. The UNEP convention on biodiversity and its implications for rightof-way selection and development, pp 269-275. In Doucet, G.J., C. Séguin, and M. Giguère (Eds.). Proceedings of the 5th International Symposium on Environmental Concerns in Rights-of-Way Management, September 19-22, 1993, Montréal, QC.

Hay, K.G., and B.A. Mohrman. 1995. Utility corridors as greenways: New opportunities for multiple use and public support, pp 367-370. In Doucet, G.J., C. Séguin, and M. Giguère (Eds.). Proceedings of the 5th International Symposium on Environmental Concerns in Rights-of-Way Management, September 19-22, 1993, Montréal, QC.

Hill, J.D., C.D. Canham, and D.M. Wood. 1995. Patterns and causes of resistance to tree invasion in rights-of-way. Ecol. Appl. 5:459-470.

IPM Associates, Inc. 1996. Introduction to Integrated Pest Management (IPM) for "Urban" Landscapes. www.efn.org/ ipmpa/ipmintro.html.

Jackson, L.W. 1997. A history of utility transmission right-ofway management in New York State, pp 103-110. In William, J.R., J.W. Goodrich-Mahoney, J.R. Wisniewski, and J. Wisniewski (Eds.). Proceedings of the 6th International Symposium on Environmental Concerns in Rights-of-Way Management, February 24-26, 1997, New Orleans, LA. Elsevier Science, New York, NY.

Johnstone, R.A. 1990. Vegetation management: Mowing to spraying. J. Arboric. 16(7):186-189.
1995. Vegetation management with environmental stewardship, pp 456-459. In Doucet, G.J., C. Séguin, and M. Giguère (Eds.). Proceedings of the 5th International Symposium on Environmental Concerns in Rights-of-Way Management, September 19-22, 1993, Montréal, QC. McLoughlin, K.T. 1997. Application of integrated pest management to electric utility rights-of-way vegetation management in New York State, pp 118-126. In William, J.R., J.W. Goodrich-Mahoney, J.R. Wisniewski, and J. Wisniewski (Eds.). Proceedings of the 6th International Symposium on Environmental Concerns in Rights-of-Way Management, February 24-26, 1997, New Orleans, LA. Elsevier Science, New York, NY.

- 2002. Integrated Vegetation Management: The exploration of a concept to application, pp 29-45. In Goodrich-Mahoney, J.W., D.F. Mutrie, and A. Guild (Eds.). Proceedings of the 7th International Symposium on Environmental Concerns in Rights-of-Way Management, September 9-13, 2000, Calgary, AB. Elsevier Science, New York, NY.

Niering, W.A. 1958. Principles of sound right-of-way vegetation management. Econ. Bot. 12(2):140-144.

_. 1987. Vegetation dynamics (succession and climax) in relation to plant community management. Conserv. Biol. 1(4):287-295.

Niering, W.A., and F.E. Egler. 1955. A shrub community of Viburnum lentago, stable for twenty-five years. Ecology 36:356-360.

Niering, W.A., and R.H. Goodwin. 1974. Creation of relatively stable shrublands with herbicides: Arresting "succession" on rights-of-way and pastureland. Ecology 55:784-795.

Niering, W.A., G.D. Dreyer, F.E. Egler, and J.P. Anderson, Jr. 1986. Stability of a Viburnum lentago shrub community after 30 years. Bull. Torrey Botanical Club 113(1):23-27.

Norris, L.A. 1997. Address environmental concerns with real data, pp 213-218. In William, J.R., J.W. GoodrichMahoney, J.R. Wisniewski, and J. Wisniewski (Eds.). Proceedings of the 6th International Symposium on Environmental Concerns in Rights-of-Way Management, February 24-26, 1997, New Orleans, LA. Elsevier Science, New York, NY.

Norris, L.A., F. Dost, and R. Van Bossuyt, Jr. 2002. Human health risk assessment for the use of herbicides on electric utility rights-of-way on the Allegheny National Forest, pp 649-664. In Goodrich-Mahoney, J.W., D.F. Mutrie, and A. Guild (Eds.). Proceedings of the 7th International Symposium on Environmental Concerns in Rights-of-Way Management, September 9-13, 2000, Calgary, AB. Elsevier Science, New York, NY.

Nowak, C.A. 2002. Wildlife and Integrated Vegetation Management on electric transmission line rights-of-way. 
Electric Power Research Institute, Palo Alto, CA, Technical Update 1005366.

Nowak, C.A., and L.P. Abrahamson. 1993. Vegetation management on electric transmission line rights-of-way in New York State: The Stability Approach to reducing herbicide use, pp 183-191. In Gjerstad, D.H. (Ed.). Proceedings of the International Conference on Forest Vegetation Management: Ecology, Practice and Policy, April 27-May 1, 1992, Auburn, AL. Auburn University School of Forestry Report 1993:1.

Nowak, C.A., and B.D. Ballard. 2001. Research and development in IVM. Paper presented, Environmental Stewardship of Utility Rights-of-Way Conference, June 12-13, 2001, Albany, NY.

Nowak, C.A., L.P. Abrahamson, D.J. Raynal, and D.J. Leopold. 1995. Selective vegetation management on powerline corridors in New York State: Tree density and species composition changes from 1975 to 1991, pp 153-158. In Doucet, G.J., C. Séguin, and M. Giguère (Eds.). Proceedings of the 5th International Symposium on Environmental Concerns in Rights-of-Way Management, September 19-22, 1993, Montréal, QC.

Nowak, C.A., L.P. Abrahamson, E.F. Neuhauser, C.G. Foreback, H.D. Freed, S.B. Shaheen, and C.H. Stevens. 1992. Cost-effective vegetation management on a recently cleared electric transmission line right-of-way. Weed Technol. 6:828-837.

Peterson, A.M. 1993. Effects of electric transmission rightsof-way on trout in forested headwater streams in New York. N. Am. J. Fish. Manage. 13:581-585.

Province of British Columbia. 2000. Silviculture Prescription Guidebook. British Columbia Ministry of Forests, Victoria, BC.

Ricard, J., and G.J. Doucet. 1999. Winter use of powerline rights-of-way by moose (Alces alces). Alces 35:31-40.

Shupe, S.D., K.E. Finch, and E.F. Neuhauser. 1997. A Project Habitat initiative in eastern New York State, pp 153-159. In William, J.R., J.W. Goodrich-Mahoney, J.R. Wisniewski, and J. Wisniewski (Eds.). Proceedings of the 6th International Symposium on Environmental Concerns in Rights-of-Way Management, February 24-26, 1997, New Orleans, LA. Elsevier Science, New York, NY.

Stern, V.M., R.F. Smith, R. van den Bosch, and K.S. Hagen. 1959. The integrated control concept. Hilgardia 29(2):81-101.

Swanton, C.J., and S.F. Weise. 1991. Integrated weed management: The rationale and approach. Weed Technol. 5:657-663.

Van Bossuyt, R. 1987. New England Electric System Companies' selective right-of-way management program, pp 123-127. In Byrnes, W.R., and H.A. Holt (Eds.). Proceedings of the 4th Symposium on Environmental
Concerns in Rights-of-Way Management, October 2528, 1987, Purdue University, IN.

Wagner, R.G. 1994. Toward integrated forest vegetation management. J. For. 92(11):26-30.

Wagner, R.G., and J.C. Zasada. 1991. Integrating plant autecology and silvicultural activities to prevent forest vegetation management problems. For. Chron. 67:506513.

Wells, T.C., K.D. Dalgarno, and R. Read. 2002. Reducing maintenance costs using Integrated Vegetation Management on electric utility transmission lines in British Columbia, pp 63-72. In Goodrich-Mahoney, J.W., D.F. Mutrie, and A. Guild (Eds.). Proceedings of the 7th International Symposium on Environmental Concerns in Rights-of-Way Management, September 9-13, 2000, Calgary, AB. Elsevier Science, New York, NY.

Witter, J.A., and J.L. Stoyenoff. 1996. Integrated pest management in urban and rural forests, pp 151-168 In Majumdar, S.K., E.W. Miller, and F.J. Brenner (Eds.). Forests-A Global Perspective. The Pennsylvania Academy of Science, Easton, PA.

Yahner, R.H. 2004. Wildlife responses to more than 50 years of vegetation maintenance on a Pennsylvania, U.S., rightof-way. J. Arboric. 30:123-126.

Yahner, R.H., W.C. Bramble, and W.R. Byrnes. 2001. Effect of vegetation maintenance of an electric transmission rightof-way on reptile and amphibian populations. J. Arboric. 27(1):24-29.

Acknowledgments. We have liberally shared our ideas on IVM over the past 5 years and have gained much from various organizations in terms of collegial reactions and monetary support that afforded us developmental opportunities. We acknowledge the following people and organizations for that support: Dr. Larry Abrahamson, State University of New York; Dr. Ed Neuhauser, Ken Finch, Craig Allen, and Tom Sullivan, Niagara Mohawk, a National Grid Company; Kevin McLoughlin, New York Power Authority; Dick Mider, New York State Electric and Gas; John GoodrichMahoney, Electric Power Research Institute (ERPI); Tara Masters, U.S. Environmental Protection Agency (EPA); and Paul Appelt, Environmental Consultants, Inc. We presented an earlier version of the IVM system to a group of nearly 30 practitioners at a September 2003 workshop sponsored and partially funded by SUNY-ESF, EPA, and EPRI entitled "Shrub ecology and management to promote Integrated Vegetation Management on powerline corridors," as part of the EPA's Pesticide Environmental Stewardship Program. We acknowledge formal assessments of each of the six steps by workshop participants. Comments received from anonymous reviewers on the draft manuscript were valuable and appreciated. 


\author{
${ }^{1 *}$ Associate Professor \\ ${ }^{2}$ Research Scientist \\ Faculty of Forest and Natural Resources Management \\ State University of New York College of Environmental Science \\ and Forestry \\ 1 Forestry Drive \\ Syracuse, NY 13210, U.S.
}

*Corresponding author, canowak@esf.edu.

Résumé. La gestion intégrée de la végétation est une terminologie qui est utilisée par plusieurs organisations qui ont à gérer des emprises de lignes électriques à travers l'ensemble des États-Unis. Dans plusieurs cas, cette expression (gestion intégrée de la végétation) est juste un nom appliqué en regard de vieilles approches de gestion. Cependant, la gestion intégrée de la végétation est plus qu'un simple nom. C'est un système poussé et sophistiqué de collecte d'informations, de planification, d'implantation, de révision et d'amélioration des traitements liés à la gestion de la végétation. Cette expression est utilisée pour comprendre, justifier, sélectionner, appliquer sélectivement et suivre différents types de traitement, et ce avec l'objectif global que les effets des traitements tiennent compte des caractéristiques spécifiques des sites et des écosystèmes sensibles tout en tenant compte de variables économiques et en étant socialement responsables afin de pouvoir améliorer les objectifs de gestion. À cet effet, on propose un système en six étapes de gestion intégrée de la végétation afin de donner un cadre d'activités pour aider les gestionnaires et autres intervenants à communiquer, organiser et mener les activités liées à l'entreprise de la gestion intégrée de la végétation. Chaque étape permet de produire des informations qui doivent être intégrées à l'intérieur du système de gestion. Ce système en six étapes est semblable à ceux de gestion intégrée des insectes et des maladies et autres systèmes de gestion similaire développés en agriculture et en foresterie. Nous y présentons un système intégré de gestion de la végétation avec certaines perspectives et idées originales tirées de la littérature auquel nous y incorporons de l'information et des expériences tirés de l'industrie du transport de l'électricité.
Zusammenfassung. Das Integrierte Vegetationsmanagement oder IVM wird inhaltlich von vielen Organisationen mit dem Pflegeauftrag für Überlandleitungen in den Vereinigten Staaten verwendet. In vielen Fällen ist IVM nur ein neuer Name für bereits verwendete Managementmethoden. Dennoch ist IVM mehr als ein Name. Es ist ein detailliertes und umfangreiches System zur Sammlung von Informationen, Planung, Rückschau und Verbesserung der Pflegemaßnahmen. IVM wird verwendet, um zu verstehen, anzupassen, zu wählen, selektiv anzuwenden und verschiedene Behandlungstypen zu überwachen, alles mit einem übergeordneten Ziel, standortspezifische, ökologisch und ökonomisch sensible und sozialverträgliche Behandlungen herauszubekommen, die dazuführen können, die Managementziele zu verbessern. Wir schlagen ein 6-Schritte-System vor, welches als Rahmenwerk Managern und anderen Verantwortlichen dienen kann, miteinander zu kommunizieren, organisieren und IVMProjekte zu steuern. Jeder Schritt produziert Informationen, die in das ganze System integriert werden. Unser 6-Schritt-System ist ausgestattet mit Integriertem Pflanzenschutz und anderen IVMähnlichen Systemen, die für Land- und Forstwirtschaft entwickelt wurden. Wir stellen ein IVM-System vor mit einigen besonderen Perspektiven und Ideen aus der Literatur und fügen Informationen aus und Erfahrungen mit der Elektroindustrie ein.

Resumen. El Manejo Integrado de la Vegetación, o IVM, es utilizado principalmente por muchas organizaciones de manejo de derecho de vía a través de los Estados Unidos. En muchos casos, IVM es solo un nombre aplicado a las tradicionales aproximaciones de manejo. Aún así, IVM es más que un nombre. Es un profundo y sofisticado sistema de información para obtención, planeación, implementación, revisión y mejoramiento de los tratamientos de manejo de vegetación. IVM es usado para entender, justificar, escoger, aplicar selectivamente y monitorear diferentes tipos de tratamientos, con el objetivo de extraer los efectos de estos tratamientos de una manera social, económica y ecológicamente responsable y de esta forma refinar los objetivos del manejo. Se propuso un sistema de seis pasos a IVM que pueda actuar como una estructura de actividades para ayudar a los manejadores en la organización y conducción de sus negocios en IVM. Cada paso produce información que puede ser integrada en el sistema de manejo. Nuestro sistema de seis pasos es consistente con el Manejo Integrado de Plagas y otros sistemas parecidos a IVM desarrollados en forestería y agricultura. Presentamos un sistema IVM con algunas perspectivas e ideas de la literatura, e información incorporada de la experiencia propia en la industria de servicios eléctricos. 